\title{
Effects of potassium chloride and nitric oxide on growth and physiological characteristics of winter wheat under salt stress
}

\author{
Y.J. DONG ${ }^{1}$, Q. ZHANG ${ }^{1}$, X.L. DAI ${ }^{2}$, and M.R. $\mathrm{HE}^{2 *}$ \\ College of Resources and Environment, Shandong Agricultural University, Tai'an 271018, P.R. China ${ }^{1}$ \\ College of Agronomic Sciences, Shandong Agricultural University, Tai'an 271018, P.R. China ${ }^{2}$
}

\begin{abstract}
A hydroponic culture was conducted to evaluate the effects of $\mathrm{KCl}$ and sodium nitroprusside (SNP; a nitric oxide donor) in wheat seedlings under salt stress. Exposure to $100 \mathrm{mM} \mathrm{NaCl}$ for $7 \mathrm{~d}$ decreased biomass of wheat seedlings, root activity and $\mathrm{H}^{+}$-ATPase activity, significantly increased free proline content, reactive oxygen species (ROS) accumulation and lipid peroxidation, and suppressed the activity of superoxide dismutase (SOD). Moreover, $\mathrm{NaCl}$ stress significantly decreased the $\mathrm{K}^{+}$and increased the $\mathrm{Na}^{+}$content. Addition of $\mathrm{KCl}$ or SNP led to the increase in root activity and soluble protein content, stimulated the activity of SOD, and decreased free proline content, superoxide anion radical generation rate, and lipid peroxidation. The increased $\mathrm{K}^{+}$and decreased $\mathrm{Na}^{+}$content in the leaves of treated seedlings indicated that suitable $\mathrm{KCl}$ and $\mathrm{NO}$ addition stimulated the selective transport of $\mathrm{K}^{+}$and $\mathrm{Na}^{+}$to the maintain $\mathrm{K}^{+} / \mathrm{Na}^{+}$homeostasis.
\end{abstract}

Additional key words: chlorophyll, CAT, ion homeostasis, malondialdehyde, POD, proline, ROS, SOD, Triticum aestivum.

\section{Introduction}

Soil salinity is one of the main factors that affect plant growth and lead to crop yield reduction (Abd El Gawad et al. 2016). Salt stress inhibits plants growth mainly by causing ion imbalance and osmotic stress (Khan et al. 2012). There exists a continuous spectrum of resistance to salinity ranging from glycophytes, which are sensitive to salinity, to halophytes, which can survive and grow under high salt concentrations (Glenn et al. 1999). The high concentration $\mathrm{NaCl}$ can reduce the soil water potential and so water uptake by roots. At the same time, the stomata of leaves are closed and the chloroplasts are damaged, which results in the decrease of photosynthetic and production rate. Salt stress also causes an accumulation of large number of ROS, causing oxidative damage to lipids, proteins, and amino acids also resulting in decreased crop yield (Foyer et al. 2000, Abreu et al. 2013). Among different salt resistance mechanisms, regulation of ion homeostasis in various tissues and intracellular compartmentalization of various ions is very important (Bressan et al. 2008). During salt stress, $\mathrm{Na}^{+}$taken in by the cell must be extruded at plasma membrane and/or compartmentalized into the vacuole. This requires up-regulation of tonoplast and plasma membrane $\mathrm{Na}^{+}$transporters. Meanwhile, the plants under salt stress accumulate a number of compatible solutes, such as soluble sugars, proline, and glycine betaine. They can function in osmotic adjustment, or act as signalling molecules to activate some specific transduction pathways (Misra et al. 2009). Secondary stresses such as oxidative damage often occur (Mittler et al. 2002, Xu et al. 2015) as a consequence of excess production of ROS. To counteract the oxidative stress, both enzymatic and non-enzymatic antioxidants have evolved in plants (Zheng et al. 2009a, Lin et al. 2012).

Potassium fertilization which can improve crop yield under adverse conditions has been interpreted as evidence that $\mathrm{K}$ increases the resistance of plants to abiotic stresess (Cakmak et al. 2005, Marschner and Marschner 2012). Both $\mathrm{K}$ and $\mathrm{Na}$ are monovalent cations having many similar properties. Although $\mathrm{Na}$ could partially substitute the function of $\mathrm{K}$, high amount $\mathrm{Na}$ is toxic to some metabolic reaction. During salt stress, there are a decrease in $\mathrm{K}^{+}$and an increase in $\mathrm{Na}^{+}$content in plant cells. The competition between ions is influenced by the properties of the membrane transporters and by the concentrations of different ions in solution (Marschner and Marschner 2012). Plant cells must regulate cation channels, pumps,

\footnotetext{
Submitted 7 January 2019, last revision 11 April 2019, accepted 12 July 2019.

Abbreviations: CAT - catalase; $\mathrm{HO}^{*}$ - hydroxyl radical; MDA - malondialdehyde; $\mathrm{O}_{2}{ }^{--}$- superoxide anion radical; POD - peroxidase; ROS - reactive oxygen species; SNP - sodium nitroprusside; SOD - superoxide dismutase; TTF - triphenyl formazan.

Acknowledgments: This work was financially supported by the National Key Research and Development Support Program of China (2017YFD0201705), the Major Agricultural Application Technology Innovation Project of Shandong Province (SD2019ZZ021), and the Major Science and Technology Innovation Projects of Shandong Province (2017CXGC0301).

* Corresponding author; e-mail:mrhe@sdau.edu.cn
} 
or transporters at the tonoplast and plasma membranes to maintain ion homeostasis. The sodium-proton antiporters and ion channels take distinguish part in the uptake and transmission of mineral element (Serrano et al. 2001). Most higher plants have developed high selectivity in the uptake of $\mathrm{K}^{+}$compared with $\mathrm{Na}^{+}$by roots and in its transport to shoots (Tian et al. 2015). A suitable $\mathrm{K}^{+} / \mathrm{Na}^{+}$ ratio is important for the adjustment of cell function. So the $\mathrm{KCl}$ application under saline condition needs more study.

Nitric oxide is one kind of small signalling molecules in plants, and it plays an important role in plant disease resistance (Singh et al. 2017). Furthermore, NO is also proved to have a mitigating effect on abiotic stresses, such as salinity, heat, and drought (Delledonne et al. 2005, Tian et al. 2015). The signalling of NO may be via a cGMPdependent pathway or cGMP-independent pathway (Arasimowicz et al. 2007). In plants, NO signalling involves cGMP, cADP ribose, $\mathrm{Ca}^{2+}$, salicylic acid (SA), and protein kinases often overlap and cross talk with $\mathrm{H}_{2} \mathrm{O}_{2}$ signalling (Crawford et al. 2005). The NO could induce the posttranslational modification of proteins, such as tyrosine nitration, methionine oxidation, and cysteine nitrosylation. Among them, the cysteine nitrosylation is a reversible modification that can modulate protein function (Dong et al. 2016). Sokolovski et al. (2004) showed that NO through S-nitrosylation regulates the activity of $\mathrm{K}$ channels in stomata guard cells. It has been also reported that exogenous NO stimulated the expression of plasma membrane $\mathrm{H}^{+}$-ATPase under salt stress (Zhao et al. 2004, Zheng et al. 2009b).

Wheat (Triticum aestivum L.) is one of the three major grain crops. It has higher nutritive value, however, it is usually considered to be very salt-sensitive. Salt stress always causes water deficit, $\mathrm{Na}^{+}$toxicity, and nutrient deficiency. Exposure to high salinity can affect photosynthesis, protein synthesis, as well as energy and lipid metabolism, leading to growth and yield reduction (Aftab et al. 2011). Khan et al. has shown that NO and $\mathrm{CaCl}_{2}$ can reduce the impact of salt stress on wheat (2012). However, studies on the effects of application of $\mathrm{NO}$ and $\mathrm{K}$ complex on winter wheat seedlings under salt stress have not been reported yet. Therefore, in this study, the effects of exogenous $\mathrm{NO}$ and $\mathrm{K}$ on plant growth, chlorophyll content, root activity and $\mathrm{H}^{+}$-ATPase in PMs, organic solutes, ROS, antioxidant enzymes, mineral nutrient, and $\mathrm{K}^{+} / \mathrm{Na}^{+}$homeostasis in winter wheat seedling under $\mathrm{NaCl}$ stress were studied in hydroponic culture.

\section{Materials and methods}

Plants and treatments: Seeds of winter wheat (Triticum aestivum L. cv. Jimai 4) were surface sterilized with $10 \%$ $(\mathrm{m} / \mathrm{v}) \mathrm{NaClO}$ solution for $10 \mathrm{~min}$, then vigorously rinsed with distilled water. Sterilized seeds were sown in plug tray and placed in a Spx-250ic (Shanghai Boxun Industry, Shanghai, China) climate box under the day/night temperatures of $25 / 20^{\circ} \mathrm{C}$, an irradiance of $150 \mu \mathrm{mol} \mathrm{m} \mathrm{m}^{-2} \mathrm{~s}^{-1}$, a $14-\mathrm{h}$ photoperiod, and a $60 \%$ relative humidity). Two fully expanded leaves were developed after $14 \mathrm{~d}$. Then the seedlings were transplanted to glassware $(6.0 \times 3.5$ $\times 10.0 \mathrm{~cm}^{3}$ ) filled with half strength Hoagland solution (containing $2.5 \mathrm{mM} \mathrm{K}^{+}$). The treatments were as follows: T1 - control (CK); T2 - $100 \mathrm{mM} \mathrm{NaCl}$; T3 - $100 \mathrm{mM} \mathrm{NaCl}$ $+10 \mathrm{mM} \mathrm{KCl}$; T4 - $0.10 \mathrm{mM}$ SNP; T5 - $100 \mathrm{mM} \mathrm{NaCl}$ + $0.10 \mathrm{mM}$ SNP; T6 - $100 \mathrm{mM} \mathrm{NaCl}+10 \mathrm{mM} \mathrm{KCl}+$ $0.10 \mathrm{mM}$ SNP. The nutrient solution was adjusted to $\mathrm{pH} 6.5$ - 6.8. Each variant included fifty seedlings and represented one replicate, and there were three replicates per treatment. The nutrient solutions were changed every day to maintain constant $\mathrm{NaCl}, \mathrm{KCl}$, and SNP concentrations. The plants were sampled after $7 \mathrm{~d}$ of treatments, the shoots and roots were separated, and fresh and dry masses estimated. The water content (WC) was determined as [(fresh mass - dry mass $) /$ fresh mass $] \times 100$.

Pigment content was determined according to the method of Song et al. (2017). Fresh leaves $(0.5 \mathrm{~g})$ were extracted in $2 \mathrm{~cm}^{3}$ of $95 \%(\mathrm{v} / \mathrm{v})$ ethanol for $24 \mathrm{~h}$ in the dark, and the solution was analyzed. The amounts of chlorophyll $a$, and $b$, and carotenoids were determined spectrophotometrically (Shimadzu UV-2450, Kyoto, Japan) by reading absorbances at 665,649 , and $470 \mathrm{~nm}$.

Determination of root activity and $\mathrm{H}^{+}$-ATPase in plasma membrane: As described in Duncan et al. (2004), the activity of the root can be expressed according to the amount of triphenyl formazan (TTF) resulting from 2,3,5-triphenyltetrazolium chloride (TTC) deoxidation.

A membrane fraction enriched in plasma membrane vesicles was prepared as described by Briskin et al. (1987) and ATP hydrolysis assays were performed. The $\mathrm{H}^{+}$-ATPase activity was determined by measuring the release of Pi (Ohnishi et al. 1975).

Determination of proline, soluble sugars, and protein content: Free proline content was determined as described by Bates et al. (1973) with slight modification Proline amount was determined using the methods of Bates et al. (1973) and Bai et al. (2015). After extraction with $3 \%(\mathrm{~m} / \mathrm{v})$ 5 -sulfosalicylic acid at room temperature, proline content was determined from a standard curve and calculated on a fresh mass basis. The content of soluble sugars was determined according to Giannapoulis et al. 2007). Soluble protein content was determined as described by Bradford et al. (1976) by using the Coomassie brilliant blue G-250 reagent and bovine serum albumin as standard.

Determination of $\mathrm{H}_{2} \mathrm{O}_{2}$ and malondialdehyde content, and $\mathrm{O}_{2}{ }^{-}$generation rate: For determination of $\mathrm{H}_{2} \mathrm{O}_{2}$ content, $1 \mathrm{~g}$ of fresh leaves or roots were homogenized in $2 \mathrm{~cm}^{3}$ of ice-cold acetone and centrifuged at $4000 \mathrm{~g}$ for $15 \mathrm{~min}$. Titanium reagent $\left[2 \%(\mathrm{~m} / \mathrm{v}) \mathrm{TiCl}_{2}\right.$ in concentrated $\mathrm{HCl}$ ] was added to a known volume of extract to give a $\mathrm{Ti}^{\mathrm{IV}}$ concentration of $2 \%$. The $\mathrm{Ti}-\mathrm{H}_{2} \mathrm{O}_{2}$ complex, together with unreacted $\mathrm{Ti}$, was then precipitated by adding $0.2 \mathrm{~cm}^{3}$ of $17 \mathrm{M}$ ammonia solution for each $1 \mathrm{~cm}^{3}$ of extract, then centrifuged at $4000 \mathrm{~g}$ for $15 \mathrm{~min}$, and the supernatant was discarded. The precipitate was washed five times with ice 
acetone by resuspension, drained in $1 \mathrm{M} \mathrm{H}_{2} \mathrm{SO}_{4}\left(3 \mathrm{~cm}^{3}\right)$. The absorbance of the solution was measured at $410 \mathrm{~nm}$ against blank, which had been similarly prepared but without plant tissue (Liu et al. 2014).

For the measurement of $\mathrm{O}_{2}^{--}$generation rate, $0.3 \mathrm{~g}$ fresh leaves or roots were homogenized in $3 \mathrm{~cm}^{3}$ of ice cold $50 \mathrm{mM}$ phosphate buffer saline (PBS; pH 7.0) and the homogenate was centrifuged at $10000 \mathrm{~g}$ for $10 \mathrm{~min}$. Then, $0.5 \mathrm{~cm}^{3}$ of the supernatant was added to $0.5 \mathrm{~cm}^{3}$ of a $50 \mathrm{mM}$ PBS (pH 7.8) and $0.1 \mathrm{~cm}^{3}$ of $10 \mathrm{mM}$ hydroxylamine hydrochloride. The mixture was incubated at $25^{\circ} \mathrm{C}$ for $35 \mathrm{~min}$ and to $0.5 \mathrm{~cm}^{3}$ of solution from the above mixture $0.5 \mathrm{~cm}^{3}$ of $17 \mathrm{mM}$ sulfanilamide and $0.5 \mathrm{~cm}^{3}$ of $7.8 \mathrm{mM}$ $\alpha$-naphthylamine was added. After $20 \mathrm{~min}$ of reaction, $2 \mathrm{~cm}^{3}$ of ether was added into the above solution, and mixed well. The solution was centrifuged at $1500 \mathrm{~g}$ and $4{ }^{\circ} \mathrm{C}$ for $5 \mathrm{~min}$. The absorbance of the pink supernatant was measured at $530 \mathrm{~nm}$ with the spectrophotometer. Absorbance values were calibrated to a standard curve generated with known concentrations of $\mathrm{HNO}_{2}$ (Tian et al. 2015).

The lipid peroxidation in fresh leaves was measured in terms of MDA content by the thiobarbituric acid reaction method (Heath and Packer 1968).

Antioxidant enzyme extraction and assays: For extraction of antioxidant enzymes, leaves were homogenized with $50 \mathrm{mM} \mathrm{Na} \mathrm{HPO}_{4}-\mathrm{NaH}_{2} \mathrm{PO}_{4}$ buffer (pH 7.8) containing $0.2 \mathrm{mM}$ EDTA and $2 \%$ insoluble polyvinyl pyrrolidone in a chilled mortar and pestle. The homogenate was centrifuged at $12000 \mathrm{~g}$ for $20 \mathrm{~min}$ and the resulted supernatant was used for determination of enzyme activities. The whole extraction procedure was carried out at $4{ }^{\circ} \mathrm{C}$. The SOD activity was assayed as described by Aftab et al. (2011) and Dong et al.(2019). One unit (U) of SOD activity was defined as the amount of the crude enzyme extract that is required for inhibiting the reduction rate of nitro blue tetrazolium by $50 \%$. The CAT activity was assayed as described by Shi et al. (2007). The POD activity was determined by the method described by Hammer et al. (1982) with some modifications. It was measured by monitoring the increase in absorption at $470 \mathrm{~nm}$ of a reaction mixture containing $0.25 \%(\mathrm{v} / \mathrm{v})$ guaiacol and $0.75 \%(\mathrm{v} / \mathrm{v}) \mathrm{H}_{2} \mathrm{O}_{2}$ as substrates and initiating the reaction by the addition of the crude enzyme extract.

Determination of mineral nutrients: Roots were soaked in $20 \mathrm{mM} \mathrm{Na}$-EDTA for $15 \mathrm{~min}$ to remove metal ions adhering to root surfaces, and rinsed with deionized water several times. The root and shoot samples were oven-dried for $30 \mathrm{~min}$ at $105{ }^{\circ} \mathrm{C}$, and then at $70^{\circ} \mathrm{C}$ till the materials reach their constant mass. About $0.1 \mathrm{~g}$ was mineralized and completely digested with $5 \mathrm{~cm}^{3}$ of $98 \%(\mathrm{~m} / \mathrm{v}) \mathrm{H}_{2} \mathrm{SO}_{4}$ at $200{ }^{\circ} \mathrm{C}$ with a few drops of $\mathrm{H}_{2} \mathrm{O}_{2}(30 \%, \mathrm{v} / \mathrm{v})$. The content of mineral element were estimated by atomic absorbance spectrometry (Persee TAS-990, Beijing, China).

Statistical analysis: All the data presented were the mean values, and all the treatments were repeated three times. We used the Excel 2003 software to process data and draw tables, SPSS 19.0 software for statistics, and minimal significant difference method (LSD) for difference significance test $(P<0.05)$.

\section{Results}

Treatment with $100 \mathrm{mM} \mathrm{NaCl}$ significantly decreased the plant growth, with a 13.53 and $14.23 \%$ reduction of dry mass of shoots and roots, respectively, as compared to the control (Table 1). Also water content of wheat seedlings treated with $100 \mathrm{mM} \mathrm{NaCl}$ decreased compared to the control. Addition of $\mathrm{K}^{+}$caused further inhibition of the shoots growth, but alleviated effects of $\mathrm{NaCl}$ on the roots. Moreover, the presence of SNP stimulated the growth under $\mathrm{NaCl}$ stress.

Wheat seedlings treated with $100 \mathrm{mM} \mathrm{NaCl}$ showed a significant increase in Chl $a, b$ and $a+b$ content per fresh mass unit in the leaves compared with the control (Table 1). Other treatments (except T6) also increased the chlorophyll content. However, the carotenoid content was decreased compared to the control under $\mathrm{NaCl}$ stress (Table 1).

The treatment with $0.10 \mathrm{mM}$ SNP suppressed the root activity under non-saline conditions, but the detrimental effect faded out under salt stress. Compared with CK, the root activity decreased under salt stress but less after $\mathrm{KCl}$ addition (Table 2). Treatment with $\mathrm{NaCl}$ evidently decreased the $\mathrm{H}^{+}$-ATPase activity. Addition of SNP improved the activities of $\mathrm{H}^{+}$-ATPase both under nonsaline and saline conditions, while the $\mathrm{KCl}$ addition had no effect (Table 2).

Under $\mathrm{NaCl}$ stress, significant increase of free proline content was recorded in wheat seedlings, especially in the leaves (Table 2). The content of free proline in the leaves treated with $\mathrm{NaCl}$ alone was 4.03-times higher than that in $\mathrm{CK}$. In the leaves, the application of $\mathrm{KCl}$ only slightly aleviate increase in the proline content, but the addition of NO inhibited the proline production under salt stress. Compared to T1, the content of proline in roots and leaves of different treatments had a similar trend, but there was no significant difference in the content of proline in roots. Soluble sugar content increased in the roots treated with $100 \mathrm{mM} \mathrm{NaCl}$ or $0.10 \mathrm{mM}$ SNP alone (Table 2), and the $\mathrm{SNP}$ and $\mathrm{KCl}$ addition to $\mathrm{NaCl}$ solution did not have significant effect on the sugar content. Compared to T1, the content of soluble sugar after different treatments of leaves and roots had a similar trend. The soluble protein content increased in the leaves and decreased in the roots under $100 \mathrm{mM} \mathrm{NaCl}$ stress (Table 2). The addition of $10 \mathrm{mM}$ $\mathrm{K}^{+}$elevated the soluble protein content in the leaves under $\mathrm{NaCl}$ treatment. Furthermore, under combined SNP and $\mathrm{KCl}$, there was highest soluble protein content than under other treatments (Table 2).

The $\mathrm{H}_{2} \mathrm{O}_{2}$ content of wheat seedlings increased under salt stress compared with CK (Table 3). The application of $\mathrm{KCl}$ alleviate effect of $\mathrm{NaCl}$ in leaves but enhanced it in roots. The SNP application increased the $\mathrm{H}_{2} \mathrm{O}_{2}$ content in roots and leaves under bot saline and non-saline conditions (Table 3). Under $\mathrm{NaCl}$ stress, $\mathrm{O}_{2}{ }^{-}$generation 
Table 1. Effects of $\mathrm{KCl}$ and SNP on fresh (f.m.) and dry masses (d.m.) [mg plant ${ }^{-1}$, water content (WC) [\%], and content of chlorophyll

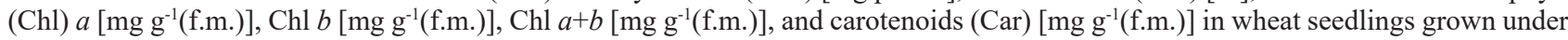
$\mathrm{NaCl}$ stress; T1 - control, T2 - $100 \mathrm{mM} \mathrm{NaCl}$, T3 - $100 \mathrm{mM} \mathrm{NaCl}+10 \mathrm{mM} \mathrm{KCl}$, T4 - $0.1 \mathrm{mM} \mathrm{SNP}$, T5 - $100 \mathrm{mM} \mathrm{NaCl}+0.1 \mathrm{mM} \mathrm{SNP}$, $\mathrm{T} 6-100 \mathrm{mM} \mathrm{NaCl}+10 \mathrm{mM} \mathrm{KCl}+0.1 \mathrm{mM}$ SNP. Means \pm SDs, $n=3$. Different letters within the same column indicate significant differences at $P<0.05$.

\begin{tabular}{lcccccc}
\hline & T1 & T2 & T3 & T4 & T5 & T6 \\
\hline Shoot f.m. & $331.94 \pm 56.37 \mathrm{a}$ & $238.19 \pm 52.81 \mathrm{~b}$ & $183.91 \pm 20.15 \mathrm{~b}$ & $324.75 \pm 37.78 \mathrm{a}$ & $310.47 \pm 19.34 \mathrm{a}$ & $213.77 \pm 5.20 \mathrm{~b}$ \\
Shoot d.m. & $34.80 \pm 5.21 \mathrm{a}$ & $30.09 \pm 4.71 \mathrm{ab}$ & $23.08 \pm 1.04 \mathrm{c}$ & $36.56 \pm 5.32 \mathrm{a}$ & $35.95 \pm 1.71 \mathrm{a}$ & $27.21 \pm 2.10 \mathrm{bc}$ \\
Shoot WC & $89.49 \pm 0.23 \mathrm{a}$ & $87.24 \pm 0.98 \mathrm{~b}$ & $87.39 \pm 0.90 \mathrm{~b}$ & $88.76 \pm 0.65 \mathrm{a}$ & $88.41 \pm 0.44 \mathrm{ab}$ & $87.28 \pm 0.71 \mathrm{~b}$ \\
Root f.m. & $78.34 \pm 12.93 \mathrm{a}$ & $51.05 \pm 5.29 \mathrm{~b}$ & $68.11 \pm 2.74 \mathrm{ab}$ & $70.68 \pm 15.95 \mathrm{ab}$ & $77.52 \pm 23.99 \mathrm{a}$ & $60.50 \pm 6.80 \mathrm{ab}$ \\
Root d.m. & $7.59 \pm 0.96 \mathrm{ab}$ & $6.51 \pm 0.62 \mathrm{~b}$ & $8.50 \pm 0.34 \mathrm{ab}$ & $7.75 \pm 1.02 \mathrm{ab}$ & $9.21 \pm 2.49 \mathrm{a}$ & $7.70 \pm 0.42 \mathrm{ab}$ \\
Root WC & $90.25 \pm 0.91 \mathrm{a}$ & $87.22 \pm 1.02 \mathrm{~b}$ & $87.50 \pm 0.92 \mathrm{~b}$ & $88.86 \pm 1.24 \mathrm{ab}$ & $88.00 \pm 0.82 \mathrm{~b}$ & $87.17 \pm 1.37 \mathrm{~b}$ \\
Chl $a$ & $1115.06 \pm 73.53 \mathrm{ab}$ & $1292.70 \pm 56.41 \mathrm{a}$ & $1143.90 \pm 129.51 \mathrm{ab}$ & $1122.36 \pm 152.13 \mathrm{ab}$ & $1229.10 \pm 151.77 \mathrm{ab} 1094.74 \pm 48.13 \mathrm{~b}$ \\
Chl $b$ & $339.95 \pm 25.71 \mathrm{~b}$ & $392.59 \pm 18.09 \mathrm{ab}$ & $333.97 \pm 39.93 \mathrm{~b}$ & $347.33 \pm 32.47 \mathrm{~b}$ & $438.93 \pm 58.89 \mathrm{a}$ & $337.17 \pm 27.00 \mathrm{~b}$ \\
Chl $a+b$ & $1455.01 \pm 90.24 \mathrm{a}$ & $1685.29 \pm 72.55 \mathrm{a}$ & $1477.87 \pm 168.83 \mathrm{a}$ & $1469.69 \pm 180.82 \mathrm{a}$ & $1668.03 \pm 210.65 \mathrm{a}$ & $1431.92 \pm 72.63 \mathrm{a}$ \\
Car & $395.87 \pm 20.76 \mathrm{a}$ & $286.69 \pm 13.85 \mathrm{~b}$ & $249.04 \pm 24.60 \mathrm{~b}$ & $305.57 \pm 88.08 \mathrm{~b}$ & $227.88 \pm 63.56 \mathrm{~b}$ & $234.15 \pm 10.95 \mathrm{~b}$ \\
\hline
\end{tabular}

Table 2. Effects of $\mathrm{KCl}$ and SNP on root activity $\left[\mu \mathrm{g} \mathrm{g} \mathrm{g}^{-1}(\mathrm{f} . \mathrm{m}.) \mathrm{h}^{-1}\right], \mathrm{H}^{+}$-ATPase activity [ $\mu \mathrm{mol}(\mathrm{Pi}) \mathrm{mg}^{-1}\left(\right.$ protein) $\left.\cdot \mathrm{h}^{-1}\right)$, and content of free proline $\left[\mu \mathrm{g} \mathrm{g}^{-1}\right.$ (f.m.)], soluble sugars [ $\mathrm{mg} \mathrm{g}^{-1}$ (f.m.)], and soluble proteins $\left[\mathrm{mg} \mathrm{g}^{-1}\right.$ (f.m.)] in leaves and roots of wheat seedlings under $\mathrm{NaCl}$ stress; T1 - control, T2 - $100 \mathrm{mM} \mathrm{NaCl}$, T3 - $100 \mathrm{mM} \mathrm{NaCl}+10 \mathrm{mM} \mathrm{KCl}$, T4 - $0.1 \mathrm{mM} \mathrm{SNP}$, T5 - $100 \mathrm{mM} \mathrm{NaCl}+0.1 \mathrm{mM} \mathrm{SNP}$, $\mathrm{T} 6-100 \mathrm{mM} \mathrm{NaCl}+10 \mathrm{mM} \mathrm{KCl}+0.10 \mathrm{mM}$ SNP. Means \pm SDs, $n=3$. Different letters within the same column indicate significant differences at $P<0.05$.

\begin{tabular}{lllllllll}
\hline Treatment & $\begin{array}{l}\text { Roots } \\
\text { Root activity }\end{array}$ & $\mathrm{H}^{+}$-ATPase & Proline & Sugars & Proteins & $\begin{array}{l}\text { Roots } \\
\text { Proline }\end{array}$ & Sugars & Proteins \\
\hline T1 & $37.30 \pm 5.57 \mathrm{a}$ & $0.07 \pm 0.01 \mathrm{bc}$ & $22.31 \pm 4.59 \mathrm{c}$ & $6.49 \pm 0.84 \mathrm{a}$ & $14.20 \pm 2.29 \mathrm{c}$ & $8.41 \pm 0.77 \mathrm{~b}$ & $5.26 \pm 0.23 \mathrm{~b}$ & $7.07 \pm 0.18 \mathrm{ab}$ \\
$\mathrm{T} 2$ & $31.27 \pm 2.36 \mathrm{a}$ & $0.06 \pm 0.00 \mathrm{c}$ & $89.96 \pm 10.73 \mathrm{a}$ & $5.90 \pm 0.14 \mathrm{ab}$ & $18.24 \pm 0.97 \mathrm{ab}$ & $25.91 \pm 13.12 \mathrm{a}$ & $6.90 \pm 0.44 \mathrm{a}$ & $3.36 \pm 1.09 \mathrm{c}$ \\
$\mathrm{T} 3$ & $36.03 \pm 1.50 \mathrm{a}$ & $0.06 \pm 0.01 \mathrm{bc}$ & $83.17 \pm 10.60 \mathrm{a}$ & $6.02 \pm 0.50 \mathrm{ab}$ & $19.12 \pm 2.26 \mathrm{ab}$ & $17.06 \pm 5.01 \mathrm{ab}$ & $4.37 \pm 0.26 \mathrm{~b}$ & $4.71 \pm 1.30 \mathrm{c}$ \\
$\mathrm{T} 4$ & $19.26 \pm 3.34 \mathrm{~b}$ & $0.08 \pm 0.01 \mathrm{a}$ & $18.07 \pm 6.26 \mathrm{c}$ & $5.84 \pm 0.08 \mathrm{ab}$ & $16.45 \pm 2.30 \mathrm{bc}$ & $12.08 \pm 1.83 \mathrm{~b}$ & $7.14 \pm 0.50 \mathrm{a}$ & $5.31 \pm 1.43 \mathrm{bc}$ \\
$\mathrm{T} 5$ & $32.66 \pm 2.27 \mathrm{a}$ & $0.07 \pm 0.00 \mathrm{bc}$ & $59.92 \pm 5.26 \mathrm{~b}$ & $5.55 \pm 0.07 \mathrm{~b}$ & $17.03 \pm 1.26 \mathrm{bc}$ & $17.83 \pm 4.40 \mathrm{ab}$ & $5.14 \pm 0.81 \mathrm{~b}$ & $3.89 \pm 0.94 \mathrm{c}$ \\
$\mathrm{T} 6$ & $35.85 \pm 6.91 \mathrm{a}$ & $0.07 \pm 0.00 \mathrm{ab}$ & $53.40 \pm 2.71 \mathrm{~b}$ & $5.48 \pm 0.47 \mathrm{~b}$ & $20.55 \pm 1.319 \mathrm{a}$ & $14.43 \pm 5.32 \mathrm{~b}$ & $4.67 \pm 1.00 \mathrm{~b}$ & $8.18 \pm 1.56 \mathrm{a}$ \\
\hline
\end{tabular}

rate significantly increased in the roots (Table 3 ). The highest values were recorded in the roots of wheat seedlings treated with $\mathrm{NaCl}$ alone, which were 3.21-times higher than in $\mathrm{CK}$. However, the presence of SNP and $\mathrm{KCl}$ significantly inhibited the $\mathrm{O}_{2}{ }^{-}$generation rate in leaves and roots compared with $\mathrm{NaCl}$ alone (Table 3). The highest values of MDA in this paper were also recorded both in leaves and roots treated with $\mathrm{NaCl}$ alone. Addition of SNP also increased the MDA production, but the combination of $\mathrm{KCl}+\mathrm{SNP}$ decreased the MDA content to values similar to those in CK (Table 3).

The salt stressed leaves showed a significant decrease in the activity of SOD, but application of $\mathrm{NO}$ and $\mathrm{KCl}$ alleviated this decrease (Table 3 ). The decreased tendency of SOD activity was in accordance with the increase of $\mathrm{O}_{2}{ }^{-}$generation rate. The activities of CAT and POD slightly increased under salt stress, in both roots and leaves. (Table 3).

Under $\mathrm{NaCl}$ stress, there was a decrease in $\mathrm{K}$ content in leaves and an increase in $\mathrm{Na}$ content in both leaves and roots as expected. However, a decrease of $\mathrm{Mg}$ and $\mathrm{Zn}$ content and an increase of $\mathrm{Ca}$ and $\mathrm{Fe}$ content were observed in wheat roots under $100 \mathrm{mM} \mathrm{NaCl}$ stress compared with
CK. When PSN was added, the $\mathrm{Na}, \mathrm{Ca}, \mathrm{Mg}, \mathrm{Zn}, \mathrm{Fe}$, and $\mathrm{Cu}$ content increased in leaves without $\mathrm{NaCl}$ stress. Under salt stress, the addition of NO did not have significant effect on the mineral element, while the presence of $\mathrm{KCl}$ decreased the content of the $\mathrm{Na}$ and $\mathrm{Ca}$ in leaves and $\mathrm{Na}$, $\mathrm{Zn}, \mathrm{Mg}, \mathrm{Cu}$, and $\mathrm{Fe}$ in the roots. Moreover, $\mathrm{NaCl}$ treatment increased leaf/root $\mathrm{Na}^{+}$content ratio and decreased leaf/ root $\mathrm{Na}^{+}$content ratio compared with other treatments. When $10 \mathrm{mM} \mathrm{KCl}$ added to the saline solution, the wheat leaves got a higher $\mathrm{K}^{+} / \mathrm{Na}^{+}$ratio compared with the $\mathrm{NaCl}$ treatment alone. The combined $\mathrm{NO}$ and $\mathrm{K}$ treatment led to the highest $\mathrm{K}^{+} / \mathrm{Na}^{+}$ratio in leaves and roots under salt conditions.

\section{Discussion}

$\mathrm{NaCl}$ treatment reduced the growth of wheat seedlings in the present study (Table 1), which might be consequence of unfavourable effect of salt stress on the various physiological processes such as photosynthesis, nutrient homeostasis, accumulation of compatible solutes, and activities of antioxidant enzymes (Aftab et al. 2011). The 
Table 3. Effects of $\mathrm{KCl}$ and $\mathrm{NO}$ on content of $\mathrm{H}_{2} \mathrm{O}_{2}$ [ $\mu \mathrm{mol} \mathrm{g}{ }^{-1}$ (f.m.)], superoxide anion $\left(\mathrm{O}_{2}{ }^{*}\right)$ generation rate $\left[\mu \mathrm{mol} \mathrm{g}^{-1}\left(\mathrm{f} . \mathrm{m}\right.\right.$.) minn ${ }^{-1}$, content of malondialdehyde (MDA) [nmol g-1(f.m.)], and activities of superoxide dismutase (SOD) [U g ${ }^{-1}$ (f.m.)], catalase (CAT) [ $\mu \mathrm{mol} \mathrm{H} \mathrm{H}_{2} \mathrm{Og}^{-1}$ (f.m.) $\mathrm{min}^{-1}$, and peroxidase (POD) $\left[\mathrm{U} \mathrm{g}^{-1}\right.$ (f.m.) $\mathrm{min}^{-1}$ ] in leaves and roots of wheat seedlings under $\mathrm{NaCl}$ stress; $\mathrm{T} 1$ control, T2 - $100 \mathrm{mM} \mathrm{NaCl}, \mathrm{T} 3-100 \mathrm{mM} \mathrm{NaCl}+10 \mathrm{mM} \mathrm{KCl}, \mathrm{T} 4-0.1 \mathrm{mM}$ SNP, T5 - $100 \mathrm{mM} \mathrm{NaCl}+0.1 \mathrm{mM} \mathrm{SNP}, \mathrm{T} 6-100 \mathrm{mM} \mathrm{NaCl}$ $+10 \mathrm{mM} \mathrm{KCl}+0.10 \mathrm{mM} \mathrm{SNP}$. Means $\pm \mathrm{SDs}, n=3$. Different letters indicate significant differences at $P<0.05$.

\begin{tabular}{lllllllc}
\hline & & $\mathrm{H}_{2} \mathrm{O}_{2}$ & $\mathrm{O}_{2}{ }^{-}$ & $\mathrm{MDA}$ & $\mathrm{SOD}$ & $\mathrm{CAT}$ & POD \\
\hline Leaves & $\mathrm{T} 1$ & $20.81 \pm 1.46 \mathrm{~b}$ & $1.39 \pm 0.05 \mathrm{~cd}$ & $3.51 \pm 1.07 \mathrm{~cd}$ & $165.11 \pm 17.21 \mathrm{c}$ & $2.08 \pm 0.09 \mathrm{~b}$ & $92.65 \pm 4.45 \mathrm{c}$ \\
& $\mathrm{T} 2$ & $23.69 \pm 2.42 \mathrm{a}$ & $5.84 \pm 0.55 \mathrm{a}$ & $13.13 \pm 0.97 \mathrm{a}$ & $146.19 \pm 9.74 \mathrm{~d}$ & $2.23 \pm 0.02 \mathrm{ab}$ & $101.24 \pm 3.83 \mathrm{ab}$ \\
& $\mathrm{T} 3$ & $20.62 \pm 1.72 \mathrm{~b}$ & $1.64 \pm 0.20 \mathrm{~cd}$ & $4.65 \pm 1.10 \mathrm{c}$ & $186.61 \pm 8.15 \mathrm{~b}$ & $1.51 \pm 0.14 \mathrm{c}$ & $96.97 \pm 4.14 \mathrm{bc}$ \\
& $\mathrm{T} 4$ & $21.29 \pm 0.52 \mathrm{ab}$ & $2.30 \pm 0.15 \mathrm{~b}$ & $9.74 \pm 0.08 \mathrm{~b}$ & $116.74 \pm 3.85 \mathrm{e}$ & $2.20 \pm 0.22 \mathrm{~b}$ & $90.27 \pm 7.26 \mathrm{c}$ \\
& $\mathrm{T} 5$ & $21.42 \pm 0.39 \mathrm{ab}$ & $1.73 \pm 0.16 \mathrm{c}$ & $12.52 \pm 0.85 \mathrm{a}$ & $205.02 \pm 7.04 \mathrm{a}$ & $2.47 \pm 0.07 \mathrm{a}$ & $107.45 \pm 2.81 \mathrm{a}$ \\
\multirow{6}{*}{ Roots } & $\mathrm{T} 6$ & $21.77 \pm 0.74 \mathrm{ab}$ & $1.19 \pm 0.13 \mathrm{~d}$ & $3.06 \pm 0.53 \mathrm{~d}$ & $199.43 \pm 8.83 \mathrm{ab}$ & $2.32 \pm 0.22 \mathrm{ab}$ & $103.03 \pm 4.37 \mathrm{ab}$ \\
& $\mathrm{T} 1$ & $10.20 \pm 0.32 \mathrm{c}$ & $3.14 \pm 0.23 \mathrm{c}$ & $3.61 \pm 0.82 \mathrm{~b}$ & $131.54 \pm 15.33 \mathrm{~b}$ & $0.40 \pm 0.09 \mathrm{bc}$ & $78.89 \pm 2.16 \mathrm{c}$ \\
& $\mathrm{T} 2$ & $10.33 \pm 0.69 \mathrm{c}$ & $23.35 \pm 2.73 \mathrm{a}$ & $14.47 \pm 0.60 \mathrm{a}$ & $79.00 \pm 10.86 \mathrm{c}$ & $0.33 \pm 0.04 \mathrm{c}$ & $100.03 \pm 6.03 \mathrm{a}$ \\
& $\mathrm{T} 3$ & $12.92 \pm 1.54 \mathrm{ab}$ & $10.86 \pm 1.58 \mathrm{~b}$ & $4.96 \pm 0.39 \mathrm{~b}$ & $134.27 \pm 8.61 \mathrm{~b}$ & $0.37 \pm 0.02 \mathrm{bc}$ & $103.95 \pm 7.61 \mathrm{a}$ \\
& $\mathrm{T} 4$ & $13.36 \pm 1.51 \mathrm{a}$ & $4.92 \pm 0.69 \mathrm{c}$ & $4.93 \pm 0.37 \mathrm{~b}$ & $129.96 \pm 11.70 \mathrm{~b}$ & $0.46 \pm 0.01 \mathrm{ab}$ & $89.12 \pm 5.58 \mathrm{~b}$ \\
& $\mathrm{~T} 5$ & $10.28 \pm 0.35 \mathrm{c}$ & $12.85 \pm 0.93 \mathrm{~b}$ & $4.42 \pm 1.12 \mathrm{~b}$ & $123.75 \pm 13.05 \mathrm{a}$ & $0.53 \pm 0.03 \mathrm{a}$ & $86.14 \pm 4.02 \mathrm{bc}$ \\
& $\mathrm{T} 6$ & $11.55 \pm 0.29 \mathrm{bc}$ & $11.23 \pm 0.37 \mathrm{~b}$ & $3.81 \pm 1.60 \mathrm{~b}$ & $187.11 \pm 6.25 \mathrm{~b}$ & $0.55 \pm 0.13 \mathrm{a}$ & $102.81 \pm 7.13 \mathrm{a}$ \\
\hline
\end{tabular}

Table 4. Effects of $\mathrm{KCl}$ and $\mathrm{SNP}$ on content of $\mathrm{K}, \mathrm{Na}, \mathrm{Cu}, \mathrm{Zn}\left[\mathrm{mg} \mathrm{kg}^{-1}(\mathrm{~d} . \mathrm{m}).\right]$, Fe, $\mathrm{Ca}$, and $\mathrm{Mg}$ [g kg-1 (d.m.)], in wheat seedlings under $\mathrm{NaCl}$ stress; T1 - control, T2 - $100 \mathrm{mM} \mathrm{NaCl}, \mathrm{T} 3-100 \mathrm{mM} \mathrm{NaCl}+10 \mathrm{mM} \mathrm{KCl}, \mathrm{T} 4-0.1 \mathrm{mM}$ SNP, T5 - $100 \mathrm{mM} \mathrm{NaCl}+0.1 \mathrm{mM} \mathrm{SNP}$, $\mathrm{T} 6-100 \mathrm{mM} \mathrm{NaCl}+10 \mathrm{mM} \mathrm{KCl}+0.10 \mathrm{mM}$ SNP. Means $\pm \mathrm{SDs}, n=3$. Different letters within the same column indicate significant differences at $P<0.05$.

\begin{tabular}{|c|c|c|c|c|c|c|c|c|c|}
\hline \multicolumn{2}{|c|}{ Treatment } & \multirow{2}{*}{$\frac{\mathrm{K}}{18.58 \pm 1.85 \mathrm{a}}$} & \multirow{2}{*}{$\frac{\mathrm{Na}}{4.52 \pm 1.35 \mathrm{~d}}$} & \multirow{2}{*}{$\begin{array}{l}\mathrm{K} / \mathrm{Na} \\
2.54 \pm 0.62 \mathrm{a}\end{array}$} & \multirow{2}{*}{$\frac{\mathrm{Ca}}{1.79 \pm 0.20 \mathrm{~b}}$} & \multirow{2}{*}{$\frac{\mathrm{Mg}}{2.18 \pm 0.18 \mathrm{a}}$} & \multirow{2}{*}{$\frac{\mathrm{Zn}}{137.9 \pm 13.5 \mathrm{a}}$} & \multirow{2}{*}{$\frac{\mathrm{Fe}}{48.54 \pm 7.35 \mathrm{~b}}$} & \multirow{2}{*}{$\frac{\mathrm{Cu}}{25.62 \pm 1.87 \mathrm{ab}}$} \\
\hline Leaves & $\mathrm{T} 1$ & & & & & & & & \\
\hline & $\mathrm{T} 2$ & $15.47 \pm 0.23 b$ & $31.58 \pm 3.38 \mathrm{a}$ & $0.29 \pm 0.03 \mathrm{c}$ & $2.45 \pm 0.52 \mathrm{ab}$ & $2.16 \pm 0.10 \mathrm{a}$ & $136.0 \pm 7.6 \mathrm{a}$ & $56.39 \pm 4.05 \mathrm{ab}$ & $21.51 \pm 0.62 b c$ \\
\hline & $\mathrm{T} 3$ & $18.14 \pm 1.35 \mathrm{a}$ & $17.93 \pm 2.52 b$ & $0.60 \pm 0.04 b c$ & $1.44 \pm 0.33 b$ & $2.02 \pm 0.11 \mathrm{a}$ & $170.3 \pm 53.9 \mathrm{a}$ & $60.44 \pm 7.44 \mathrm{a}$ & $22.80 \pm 2.33 b c$ \\
\hline & $\mathrm{T} 4$ & $17.87 \pm 2.01 \mathrm{ab}$ & $11.75 \pm 1.90 \mathrm{c}$ & $0.91 \pm 0.18 \mathrm{~b}$ & $3.49 \pm 1.21 \mathrm{a}$ & $2.21 \pm 0.25 \mathrm{a}$ & $159.7 \pm 17.4 \mathrm{a}$ & $53.16 \pm 8.81 \mathrm{ab}$ & $28.72 \pm 2.69 a$ \\
\hline & $\mathrm{T} 5$ & $16.75 \pm 1.77 \mathrm{ab}$ & $20.59 \pm 2.16 b$ & $0.48 \pm 0.05 \mathrm{bc}$ & $1.41 \pm 0.44 \mathrm{~b}$ & $2.10 \pm 0.13 a$ & $132.6 \pm 12.8 \mathrm{a}$ & $59.46 \pm 5.03 \mathrm{ab}$ & $19.71 \pm 4.31 \mathrm{c}$ \\
\hline & T6 & $17.20 \pm 0.85 \mathrm{ab}$ & $17.42 \pm 0.95 b$ & $0.99 \pm 0.05 \mathrm{bc}$ & $1.49 \pm 0.14 b$ & $2.13 \pm 0.08 \mathrm{a}$ & $154.3 \pm 8.4 \mathrm{a}$ & $60.72 \pm 4.63 \mathrm{a}$ & $23.39 \pm 0.78 b c$ \\
\hline \multirow[t]{6}{*}{ Roots } & $\mathrm{T} 1$ & $17.54 \pm 2.06 \mathrm{a}$ & $7.00 \pm 1.32 \mathrm{c}$ & $1.49 \pm 0.14 \mathrm{a}$ & $0.29 \pm 0.10 \mathrm{ab}$ & $1.07 \pm 0.15 \mathrm{a}$ & $169.1 \pm 24.5 \mathrm{a}$ & $220.67 \pm 35.39 b$ & $37.76 \pm 2.16 \mathrm{ab}$ \\
\hline & $\mathrm{T} 2$ & $16.76 \pm 2.04 \mathrm{a}$ & $27.91 \pm 3.48 \mathrm{a}$ & $0.37 \pm 0.08 \mathrm{~cd}$ & $0.30 \pm 0.10 \mathrm{~b}$ & $0.91 \pm 0.11 \mathrm{ab}$ & $159.5 \pm 32.3 \mathrm{a}$ & $294.43 \pm 56.03 a$ & $40.37 \pm 7.49 a$ \\
\hline & $\mathrm{T} 3$ & $17.84 \pm 0.85 \mathrm{a}$ & $25.47 \pm 1.09 \mathrm{a}$ & $0.45 \pm 0.02 \mathrm{~cd}$ & $0.34 \pm 0.04 \mathrm{ab}$ & $0.71 \pm 0.07 \mathrm{~cd}$ & $144.2 \pm 10.8 \mathrm{a}$ & $247.57 \pm 44.61 \mathrm{ab}$ & $31.01 \pm 0.96 b$ \\
\hline & $\mathrm{T} 4$ & $17.58 \pm 2.27 \mathrm{a}$ & $16.73 \pm 3.34 b$ & $0.63 \pm 0.13 b$ & $0.31 \pm 0.08 \mathrm{ab}$ & $0.83 \pm 0.02 b c$ & $156.9 \pm 12.1 \mathrm{a}$ & $224.68 \pm 16.39 b$ & $39.52 \pm 5.39 \mathrm{ab}$ \\
\hline & $\mathrm{T} 5$ & $15.86 \pm 3.91 \mathrm{a}$ & $25.74 \pm 3.63 a$ & $0.37 \pm 0.09 \mathrm{~d}$ & $0.28 \pm 0.14 b$ & $0.71 \pm 0.15 \mathrm{~cd}$ & $163.4 \pm 12.7 \mathrm{a}$ & $245.88 \pm 30.80 \mathrm{ab}$ & $39.13 \pm 6.47 \mathrm{ab}$ \\
\hline & $\mathrm{T} 6$ & $16.88 \pm 1.98 \mathrm{a}$ & $18.983 .53 b$ & $0.53 \pm 0.04 b c$ & $0.45 \pm 0.06 \mathrm{a}$ & $0.63 \pm 0.01 \mathrm{~d}$ & $171.4 \pm 42.4 \mathrm{a}$ & $236.97 \pm 28.75 \mathrm{ab}$ & $39.14 \pm 5.08 \mathrm{ab}$ \\
\hline
\end{tabular}

salt-induced reduction in growth parameters is generally found in many different crops (Khan et al. 2012, Liu et al. 2014). However, treatment with NO donor PNS increased the fresh and dry masses of shoots and roots (Table 1). Similarly, $\mathrm{NO}$ alleviated $\mathrm{Cu}$-stress in tomato, Ni-stress in canola, and Cd-stress in ryegrass (Cui et al. 2010, Kazemi et al. 2010, Wang et al. 2013). When $10 \mathrm{mM} \mathrm{KCl}$ was added to $100 \mathrm{mM} \mathrm{NaCl}$ solution, shoot growth was more suppressed but root growth less suppressed than under $\mathrm{NaCl}$ alone (Table 1). This might be considered as adaption of wheat seedlings by increasing the root/shoot ratio.

The growth of some crop plants can be enhanced by low concentrations of $\mathrm{NaCl}(10-40 \mathrm{mM})$. Under high salinity, previous studies have showed increase or decrease chlorophyll content per fresh mass unit (Hanada et al. 1994, Santos et al. 2004), which depend on the tolerance of different plants to the salt stress. García-Valenzuela et al. (2005) proved that chlorophyll accumulation increased in response to osmotic stress in graminaceous chlorophyllic cells. In addition, some halophytes accumulate high amount of $\mathrm{Na}^{+}$for osmotic adjustment and their chloroplasts function well. It can be supposed that high salinity induced osmotic stress is the signal for the increased chlorophyll accumulation (García-Valenzuela et al. 2005). In plants, carotenoids play a role in protecting plants against photooxidative processes. The carotenoids act as a ROS-scavenging compounds, which could prevent the production of the ${ }^{1} \mathrm{O}_{2}$ (Müller et al. 2011). $\mathrm{NaCl}$ stress decreased the Car content in wheat seedlings (Table 1) and so their antioxidant capacity.

Root systems play an important role in controlling plant growth and development because of their importance in 
the absorption of water and nutrients (Qi et al. 2012). Root activities of NO-treated wheat seedlings were decreased under non-saline conditions and increased under saline condition (Table 2). The enzymatic reduction of TTC by cellular redox systems to insoluble red formazan has been used to measure viability of roots (Duncan et al. 2004). The NO donor, SNP contains $\mathrm{CN}^{-}$that may inhibit the cytochrome pathway. Furthermore, NO could affect the activities of antioxidant enzymes and the ROS accumulation under salt stress (Table 3 ), that suggests that NO can participate in the response of wheat to salt stress by regulating the activity of antioxidant enzymes and the amount of ROS. The plasma membrane $\mathrm{H}^{+}$-ATPase is a tightly bound and integral transmembrane protein. It is well known that $\mathrm{H}^{+}$-ATPase in plasma membrane plays an important role in the transport of multiple ions (Zhao et al. 2004, Wang et al. 2013). NO could induce $\mathrm{H}^{+}$-ATPase activity (Table 2), which is a benefit for the selective uptake of mineral elements. However, $10 \mathrm{mM} \mathrm{KCl}$ had no significant effect on root activity. In maize, $\mathrm{K}^{+}$activates membrane $\mathrm{H}^{+}$-ATPase and so facilitates the transport of different ions (Gibrat et al. 1990). Under $\mathrm{NaCl}$ stress, the $\mathrm{KCl}+\mathrm{SNP}$ treatment alleviated the adverse of salt stress to $\mathrm{H}^{+}$-ATPase activities. Similar result was reported in cotton seedlings under $\mathrm{NaCl}$ stress (Liu et al. 2014).

Accumulation of organic solutes in the cytosol and organelles is a good way of osmotic adjustment. Abiotic stress always results in the accumulation of proline, which was also found under salt stress in this study (Table 2). Proline accumulation is one of the most frequently reported modifications induced by salt stress in plants, and it is often considered to be a stress resistance mechanism (Misra et al. 2009). The decrease in the content of proline was observed with the addition of PSN to $\mathrm{NaCl}$ solution compared with $\mathrm{NaCl}$ alone. Reduction in proline content by NO pretreatment has been reported in canola under $\mathrm{Ni}$-stress and in ryegrass under Cd-stress (Kazemi et al. 2010, Wang et al. 2013). Lopez-Carrion et al. (2008) reported that $\mathrm{NO}$ reduced proline accumulation in cabbage under salt stress and suggested that the reduction in the proline content was related to increased activity of proline dehydrogenase. In addition, in the present study, the soluble protein content increased under $\mathrm{NaCl}$ stress in the wheat leaves, which suggests that salt stress could induce the expression of soluble protein or produce new protein to suit the saline conditions. Soluble sugar content in the $\mathrm{KCl}$ or SNP treatments was lower compared with $\mathrm{NaCl}$ alone treatment.

ROS play an important role in redox signal transduction, although they are toxic. In this study, $\mathrm{NaCl}$ treatment increased $\mathrm{O}_{2}{ }^{-}$accumulation and lipid peroxidation in wheat seedlings (Table 3). Amongst the different ROS, $\mathrm{H}_{2} \mathrm{O}_{2}$ is taken as the most stable one, so that its content is typical for the redox status. $\mathrm{H}_{2} \mathrm{O}_{2}$ is also studied as a signalling molecule (Zhang et al. 2013, Qiao et al. 2014), however, higher content of $\mathrm{H}_{2} \mathrm{O}_{2}$ is toxic and leads to programmed cell death; so it is crucial for plants to regulate $\mathrm{H}_{2} \mathrm{O}_{2}$ intracellular content (Egbichi et al. 2013). The accumulation of MDA under saline conditions reflects oxidation of membrane-bound fatty acids causing propagation of lipid peroxidation. The SOD, POD, CAT, and other antioxidant are present in different organelles in plants. The results show, that treatment with $\mathrm{KCl}$ or SNP can increase the activity of SOD (Table 3 ) and so decrease in the content of $\mathrm{O}_{2}{ }^{-}$(Table 3). The decrease of root SOD activity under $\mathrm{NaCl}$ treatments was the main reason for the significant increase of $\mathrm{O}_{2}{ }^{--}$. Moreover, the combination of $\mathrm{KCl}+\mathrm{SNP}$ showed a synergism on ROS metabolism and SOD function in wheat seedlings.

The NO is an unusual signal; it is a reactive, volatile, and lipophilic free radical that could be cytotoxic (Crawford et al. 2005). Under salt stress, the activities of SOD, POD, and CAT maintained rather high, and the content of MDA, $\mathrm{H}_{2} \mathrm{O}_{2}$ and $\mathrm{O}_{2}^{-}$decreased when treated with $\mathrm{NO}, \mathrm{KCl}$, or $\mathrm{NO}+\mathrm{KCl}$. The $\mathrm{NO}$ has been recognized to detoxify ROS either with direct interaction with superoxide or may enhance the antioxidant capacity of cell by increasing the activities of antioxidant enzymes (Khan et al. 2012). The effect of NO on ROS metabolism has been reported in many other studies (e.g. White et al. 1999, Shi et al. 2007). The reduction of ROS decreases lipid peroxidation and protein damage. On the other hand, $\mathrm{KCl}$ treatment also affect $\mathrm{ROS}$ metabolism because $\mathrm{KCl}$ treatment promotes absorption of $\mathrm{K}^{+}$and inhibits absorption of $\mathrm{Na}^{+}$, which reverses toxicity of the single ion.

Under $\mathrm{NaCl}$ stress, there was a decrease in $\mathrm{K}^{+}$uptake in the wheat seedlings and an increase in $\mathrm{Na}^{+}$influx (Table 4). The increase in $\mathrm{Na}^{+}$accumulation is in accordance with results obtained in other crop plants (Khan et al.. 2012, Liu et al. 2014). Electrophysiological studies have shown that the voltage-insensitive monovalent-cation channel (VIC) or nonselective cation channel (NSCC) are responsible for the bulk of $\mathrm{Na}^{+}$influx into plant cells (White et al. 1999). Excess of $\mathrm{Na}^{+}$is toxic to the plant cells and $\mathrm{K}^{+}$is the major ion contributing to osmotic pressure and ionic strength (Serrano et al. 2001). In this experiment, the content of $\mathrm{K}^{+}$and the $\mathrm{K}^{+} / \mathrm{Na}^{+}$ratio decreased under salt stress (Table 4). To maintain normal cell metabolism, a suitable $\mathrm{K}^{+} / \mathrm{Na}^{+}$ratio is important for the adjustment of cell osmoregulation, pressure potential, stomatal function, activation of enzymes, protein synthesis, and photosynthesis (Shabala et al. 2003, Zheng et al. 2008). Our results showed that NO evidently alleviated effect of $\mathrm{NaCl}$ on wheat seedlings. The presence of $\mathrm{NO}$ could inhibit the $\mathrm{Na}^{+}$transport and improve the $\mathrm{K}^{+}$transport from root to shoot. So, the leaves of wheat seedlings get more $\mathrm{K}^{+}$and less $\mathrm{Na}^{+}$and so improving the $\mathrm{K}^{+} / \mathrm{Na}^{+}$ratio when treated with SNP under saline condition. Under $100 \mathrm{mM}$ $\mathrm{NaCl}$, the $\mathrm{Mg}$ content in the roots slightly decreased, whereas the Fe content increased significantly (Table 4). That was the most usual phenomenon under salt stress, the ionic imbalance, which was different among various environments and plants. Though the content of $\mathrm{Ca}, \mathrm{Mg}$, $\mathrm{Zn}, \mathrm{Fe}, \mathrm{Cu}$, and $\mathrm{K}$ in wheat seedlings were influenced by $\mathrm{KCl}$ and $\mathrm{NO}, \mathrm{K}^{+}$played the key role in ion homeostasis under $\mathrm{NaCl}$ stress. The suitable $\mathrm{K}^{+} / \mathrm{Na}^{+}$ratio in nutrient solution promoted the selective capacity for $\mathrm{K}^{+}$, suppressed the uptake of $\mathrm{Na}^{+}$in root system, as well, $\mathrm{K}^{+} / \mathrm{Na}^{+}$ratio in root cells and affected the transport of $\mathrm{Na}^{+}$and $\mathrm{K}^{+}$from roots to leaves. 
In conclusion, salt stress depressed plant growth, inhibited root activity, decreased protein synthesis, caused oxidative stress, and inhibited uptake of nutrient elements. The addition of $10 \mathrm{mM} \mathrm{KCl}$ and/or $0.1 \mathrm{mM}$ SNP could alleviate the $\mathrm{NaCl}$-induced suppression in activities of $\mathrm{H}^{+}$-ATPase and antioxidant enzymes, especially SOD, decrease the $\mathrm{O}_{2}^{--}$generation rate and lipid peroxidation under salt stress. Exogenous NO had an effect on the capacity of $\mathrm{K}^{+}$and $\mathrm{Ca}^{2+}$ uptake and could promote the ratio of $\mathrm{K}^{+} / \mathrm{Na}^{+}$in the leaves. The $10 \mathrm{mM} \mathrm{KCl}$ added to $100 \mathrm{mM} \mathrm{NaCl}$ solution improved the $\mathrm{K}^{+} / \mathrm{Na}^{+}$ratio in nutrient solution, thus enhanced the selective uptake of $\mathrm{K}^{+}$compared with $\mathrm{Na}^{+}$. Furthermore, the combination of $\mathrm{KCl}$ and SNP had some positive effects on organic solutes, ROS metabolism, SOD function and $\mathrm{K}^{+} / \mathrm{Na}^{+}$ratio and can be recommend for alleviation of adverse effect of salt stress in wheat seedlings.

\section{References}

AbdElgawad, H., Zinta, G., Hegab, M.M., Pandey, R., Asard, H., Abuelsoud, W.: High salinity induces different oxidative stress and antioxidant responses in maize seedlings organs. Front.. Plant Sci. 7: 276, 2016.

Abreu, I.A., Farinha, A.P., Negrão, S., Gonçalves, N., Fonseca, C., Rodrigues, M., Batista, R., Saibo, N.J.M., Oliveira, M.M.: Coping with abiotic stress: proteome changes for crop improvement. - J. Proteomics 93: 145-168, 2013.

Aftab, T., Khan, M.M.A., da Silva, J.A.T., Idrees, M., Naeem, M., Moinuddin: Role of salicylic acid in promoting salt stress tolerance and enhanced artemisinin production in Artemisia annua L. - J. Plant Growth Regul. 30: 425-435, 2011.

Arasimowicz, M., Floryszak-Wieczorek J.,.: Nitric oxide as a bioactive signalling molecule in plant stress responses. Plant Sci. 172: 876-887, 2007.

Bai, X.Y., Dong,Y.J., Wang,Q.H., Xu, L.L., Kong, J., Liu,S.: Effects of lead and nitric oxide on photosynthesis, antioxidative ability, and mineral element content of perennial ryegrass. - Biol. Plant.59: 163-170, 2015.

Bates, L.S., Waldren, S.P., Teare, I.D.: Rapid determination of free proline for water-stress studies. - J. Plant Soil 39: 205207, 1973.

Bradford, M.M.: A rapid and sensitive method for the quantitation of microgram quantities of protein utilizing the principle of protein-dye binding. - Anal. Biochem. 72: 248-254, 1976.

Bressan, R.A., Bohnert, H.J., Hasegawa, P.M.: Genetic engineering for salinity stress tolerance. - Adv. Plant Biochem. mol .Biol 1: 347-384, 2008.

Briskin, D.P., Leonard, R.T., Hodges, T.K.: Isolation of the plasma membrane: markers and general principles. - Methods Enzymol. 148: 542-558,1987.

Cakmak, I.: The role of potassium in alleviating detrimental effects of abiotic stresses in plants. - J. Plant Nutr. Soil Sci. 168: 521-530, 2005.

Crawford, N.M., Guo, F.: New insights into nitric oxide metabolism and regulatory functions. - Trends Plant Sci. 10:195-200, 2005.

Cui, X.M., Zhang, Y.K., Wu, X.B., Liu, C.S.: The investigation of the alleviated effect of copper toxicity by exogenous nitric oxide in tomato plants. - J. Plant Soil Environ. 6: 274-281, 2010.

Delledonne, M.: NO news is good news for plants. - Curr Opin. Plant Biol. 8: 390-396, 2005
Dong, Y.J., Chen, W.F., Xu, L.L., Kong, J., Liu S., He, Z.L.: Nitric oxide can induce tolerance to oxidative stress of peanut seedlings under cadmium toxicity. - Plant Growth Regul. 79:19-28, 2016

Dong,Y.J., Wan, Y.S., Liu, F.Z., Zhuge, Y.P.: Effects of exogenous SA supplied with different approaches on growth, chlorophyll content and antioxidant enzymes of peanut growing on calcareous soil. - J. Plant Nutr. 42: 1869-1883, 2019.

Duncan, D.R., Widholm, J.M.: Osmotic induced stimulation of the reduction of the viability dye 2,3,5-triphenyltetrazolium chloride by maize roots and callus cultures. - J. Plant Physiol. 16: 397-403, 2004.

Egbichi, I., Keyster, M., Jacobs, A., Klein, A., Ludidi, N.: Modulation of antioxidant enzyme activities and metabolites ratios by nitric oxide in short-term salt stressed soybean root nodules. - South Afr. J. Bot. 88: 326-333, 2013.

Foyer, C.H., Noctor, G.: Oxygen processing in photosynthesis: regulation and signaling. - New Phytol. 146: 359-388, 2000.

García-Valenzuela, X., García-Moya, E., Rascón-Cruz, Q., Herrera-Estrella, L., Aguado-Santacruz, G.A.: Chlorophyll accumulation is enhanced by osmotic stress in graminaceous chlorophyllic cells. - J. Plant Physiol. 162: 650-661, 2005.

Giannakoula, A., Moustakas, M., Mylona, P., Ioannis, P., Traianos, Y.: Aluminium tolerance in maize is correlated with increased levels of mineral nutrients, carbohydrates and proline and decreased levels of lipid peroxidation and $\mathrm{Al}$ accumulation. - J. Plant Physiol. 165:385-396, 2007.

Gibrat, R., Grouzis, J.P., Rigaud, J., Grignon, C.: Potassium stimulation of corn root plasmalemma ATPase. - J. Plant Physiol. 93: 1183-1189, 1990.

Glenn, E.P., Brown, J.J., Blumwald, E.: Salt tolerance and crop potential of halophytes. - Crit. Rev. Plant Sci. 18: 227-255, 1999.

Hammer, S.R., Nuckles, E.M., Kuć, J.: Association of enhanced peroxidase activity with induced systemic resistance of cucumber to Colletotrchum lagenarium. - J. Physiol. Plant Pathol. 20: 73-82,1982.

Hanada, A.M., El-Enany, A.E.: Effect of $\mathrm{NaCl}$ salinity on growth, pigment and mineral element contents, and gas exchange of broad bean and pea plants. - Biol. Plant. 36: 75-81,1994.

Heath, R.L., Packer, L.: Photoperoxidation in isolated chloroplasts. I. Kinetics and stoichiometry of fatty acid peroxidation. - Arch. Biochem. Biophys. 125: 189-198, 1968.

Kazemi, N., Khavari-Nejad, R., Fahimi, H., Saadatmand, S., Nejad-Sattari, T.: Effects of exogenous salicylic acid and nitric oxide on lipid peroxidation and antioxidant enzyme activities in leaves of Brassica napus L. under nickel stress. Sci. Hort. 126: 402-407, 2010.

Khan, M.N., Siddiqui, M.H., Mohammad, F., Naeem, M.: Interactive role of nitric oxide and calcium chloride in enhancing tolerance to salt stress. - J. Nitric Oxide 27: 210218,2012

Lin, Y., Liu, Z., Shi, Q., Wang, X., Wei, M., Yang, F.: Exogenous nitric oxide (NO) increased antioxidant capacity of cucumber hypocotyl and radicle under salt stress. - Scientia Hort. 142: 118-127, 2012.

Liu, S., Dong, Y.J., Xu, L.L., Kong, J.: Effects of foliar applications of nitric oxide and salicylic acid on salt-induced changes in photosynthesis and antioxidative metabolism of cotton seedlings. - Plant Growth Regul. 73: 67-78, 2014.

Lopez-Carrion, A.I., Castellano, R., Rosales, M.A., Ruiz, J.M., Romero, L.: Role of nitric oxide under saline stress: implications on proline metabolism. - Biol. Plant. 52: 587591, 2008.

Marschner, P., Marschner,S.: Mineral Nutrition of Higher Plants. $3^{\text {rd }}$ Ed. - Science Press, Beijing 2012. 
Misra, N., Saxena, P.: Effect of salicylic acid on proline metabolism in lentil grown under salinity stress. - J. Plant Sci. $177: 181-189,2009$.

Mittler, R.: Oxidative stress, antioxidants and stress tolerance. Trends Plant Sci. 7: 405-410, 2002.

Müller, L., Fröhlich, K., Böhm, V.: Comparative antioxidant activities of carotenoids measured by ferric reducing antioxidant power (FRAP), ABTS bleaching assay ( $\alpha$ TEAC), DPPH assay and peroxyl radical scavenging assay. - Food Chem. 129: 139-148, 2011.

Ohnishi, T., Gall, R.S., Mayer, M.L.: An improved assay of inorganic phosphate in the presence of extra labile phosphate compounds: application to the ATP-ase assay in the presence of phosphocreatine. - Anal. Biochem. 69: 261-267, 1975.

Qi, W.Z., Liu, H.H., Liu, P., Dong, S.T., Zhao, B.Q., So, H.B., Li, G., Liu, H.D., Zhang, J.W., Zhao, B.: Morphological and physiological characteristics of corn roots from cultivars with different yield potentials. - Eur. J. Agron. 38: 54-63, 2012.

Qiao, W., Li, C., Fan, L.M.: Cross-talk between nitric oxide and hydrogen peroxide in plant responses to abiotic stresses. Environ. exp. Bot. 100: 84-93, 2014.

Santos, C.V.: Regulation of chlorophyll biosynthesis and degradation by salt stress in sunflower leaves. - Scientia Hort. 103: 93-99, 2004.

Serrano, R., Rodriguez-Navarro, A.: Ion homeostasis during salt stress in plants. - Curr. Opin. Plant Biol. 13: 399-404, 2001.

Shabala, S.N., Shabala, L., Van, E.V.: Effect of calcium on root development and root ion fluxes in salinised barley seedlings. - Funct. Plant Biol. 30: 507-514, 2003.

Shi, Q., Ding, F., Wang, X., Wei, M.: Exogenous nitric oxide protects cucumber roots against oxidative stress induced by salt stress. - Plant Physiol. Biochem. 45: 542-550, 2007.

Singh, A.P., Dixit, G., Kumar, A., Mishra, S., Kumar, N., Dixit, S., Singh, P.K., Dwivedi, S., Trivedi, P.K., Pandey, V., Dhankher, O.P., Norton, G.J., Chakrabarty, D., Tripathi, R.D.: A protective role for nitric oxide and salicylic acid for arsenite phytotoxicity in rice (Oryza sativa L.). - Plant Physiol. Biochem. 115: 163-173, 2017.

Sokolovski, S., Blatt, M.R.: Nitric oxide block of outwardrectifying $\mathrm{K}+$ channels indicates direct control by protein nitrosylation in guard cells. - J. Plant Physiol. 136: 4275 4284, 2004.

Song, Y. L., Dong, Y J., Tian, X.Y., Kong, J., Bai, X.Y., Xu, L.L., He, Z.L.: Role of foliar application of 24-epibrassinolide in response of peanut seedlings to iron deficiency. - Biol. Plant. 60: 329-342, 2016.

Song, Y.L., Dong, Y.J., Tian, X.Y., Wang, W.W., He, Z.L.: Effects of nitric oxide and Fe supply on recovery of Fe deficiency induced chlorosis in peanut plants. - Biol. Plant. 61: 155-168, 2017. 